\title{
Prototyping a Useless Design Practice: What, Why \& How?
}

\author{
Søren Rosenbak, \\ Umeå Institute of Design
}

\begin{abstract}
This essay sets out to rectify the false dichotomy between the notions of uselessness and usefulness in relation to design, in order to argue for a useless design practice. The argument is structured into three main parts.
\end{abstract}

Part I opens with an introduction and goes on to frame design as a hybrid discipline that has been characterized by usefulness since it was born of the Industrial Revolution. The notion of useful design and its continuingly intimate relationship with the neoliberalist growth economy is subsequently unpacked through scrutinizing the basic demands for quantification \& acceleration, conflicting use and temporality with special attention paid to the Anthropocene.

Part II elucidates the ambiguous relationship between the useless and the useful through the related critical/conformist dichotomy present in Dunne \& Raby's A/B Manifesto as well as through useless and useful design fictions. From here the unuseless chindōgu by Kawakeni and the unfindable objects by Carelman together frame the useless as a "useful overdrive." Additionally they illustrate the constant risk of assimilation, festishization and spectacle that disruptive useless design artifacts face within the neoliberalist growth economy. In the digital realm The Useless Web accentuate the post-ironic and absurd qualities in useless design.

Part III asks: what is useless design, why do we need useless design and how could useless design exist? From five opening propositions, useless design is positioned among related concepts such as Redström's "design after design" (2008), Hunt's "tactical formlessness" (2003), Tonkinwise's "designing things that are not finished" (2005), and Jones' "pure design" (1984). Useless design is finally argued to find its value from its ability to valuate and actively traverse the growing chasm between the industrial and the post-industrial design paradigm.

In essence useless design is an invitation to make useful, here "useful" understood in reappropriated terms, beyond its currently one dimensional, confined state. On that note, the essay concludes by shifting its gaze from the abstract insights gathered throughout the essay towards the concrete urgent task of prototyping a useless design practice.

Keywords: Useless design, usefulness, valuation, post-industrial design, critical practice, design activism, neoliberalism.

She wanted to get some personal profit out of things, and she rejected as useless all that did not contribute to the immediate desires of her heart... (Flaubert, 2013 [1856])

\section{PART I}

\section{Introduction}

The useless and the useful have their shared foundation in the basic notion of "use" (noun and verb), a concept so crucial for the design discipline. When we today term a design artifact as being useless or useful, it seems evident that we make a value statement: why is one design artifact deemed useful and another useless? Why do we only add these labels to certain design artifacts while leaving others without any such designation? What is the relation between the useless and the useful? And is all this fixed or does it change in time?

This essay concerns the rich elusive concepts of the useless and the useful in relation to design. When framing design through such an ambiguous lens, it becomes vital to set a certain focus, knowing that many interesting tangents will be left outside of this particular framing. The field of human-computer interaction $(\mathrm{HCl})$ is an example of one such tangent. Much important work exist within this field 


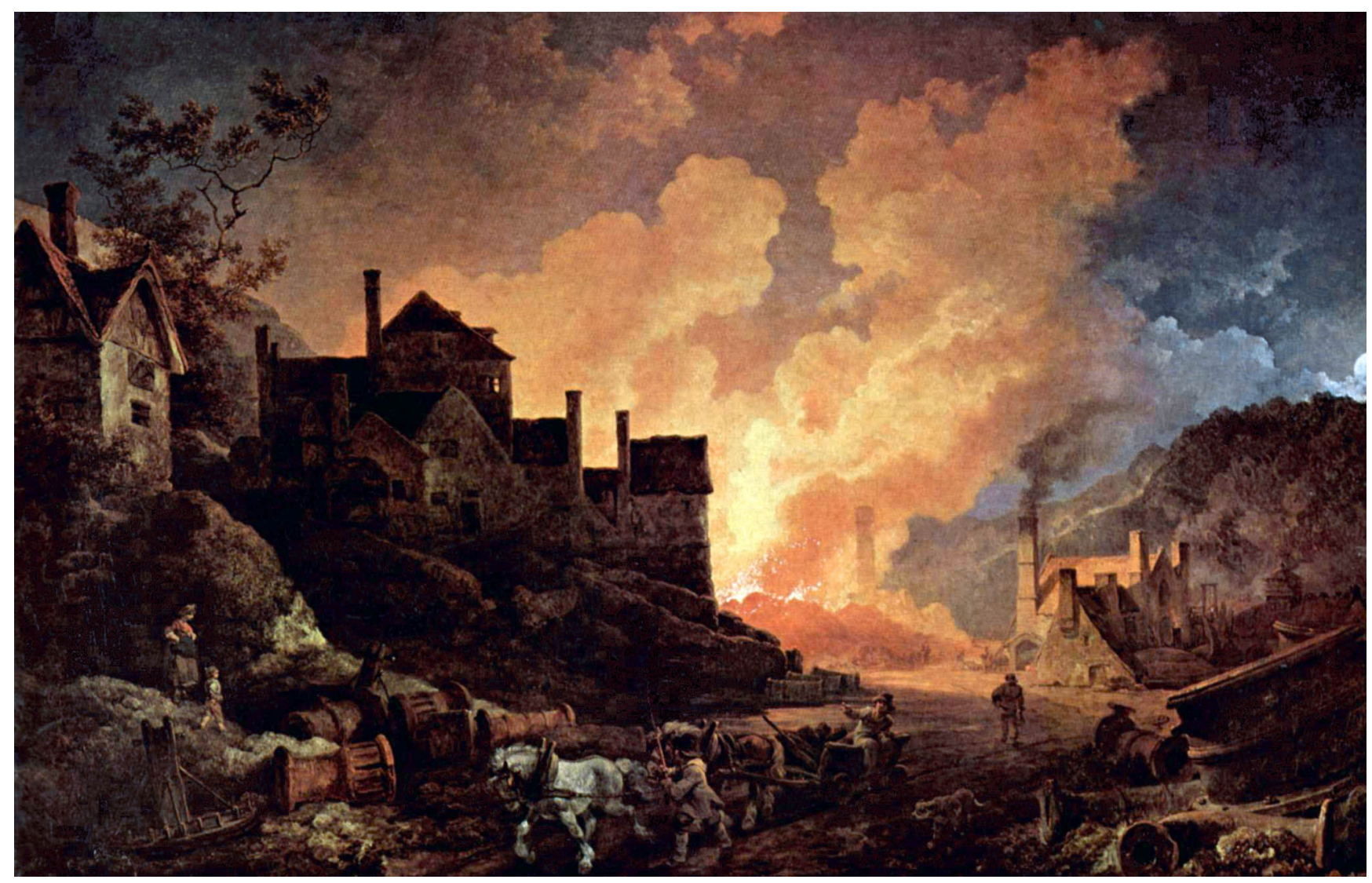

Figure 1. Philip James de Loutherbourg: Coalbrookdale by Night, 1801. Source: Wikipedia. Copyright [2002] The Yorck Project: 10.000 Meisterwerke der Malerei [DVD-ROM]. ISBN 3936122202. Distributed by DIRECTMEDIA Publishing GmbH.

discussing usefulness and uselessness in relation to interaction design, Norman's notion of affordances (2002) and the arguments by Gaver et al. for ambiguity as a resource for design (2003), to name a few major works of obvious relevance. While acknowledging the importance of the many contributions, this essay wants to take a broader critical view both in a horizontal and vertical direction: enquiring into the wider sense of the useless and useful artifact on a societal level and arguing within a two-hundred year continuum, from the industrial to the post-industrial. Thus, contextuality and temporality becomes key concerns for unraveling the dynamic relation between the useless and the useful within design. Despite the fact that the essay takes this broader view, it is important to note that the argument ultimately heads towards the concrete prototyping of a useless design practice.

It is extremely hard to avoid edging not only $\mathrm{HCl}$, but also areas such as philosophy, phenomenology, science and technology studies (STS), history, politics, sustainability, psychology etc. when venturing into the murky waters of wrangling such wicked problems that the useless/useful dichotomy poses for design. However, I would consider any provisional interface that may arise as an invitation rather than a trespassing. I would further hope for a continued discussion around the useless and the useful across fields and disciplines, within and beyond design.

\section{A Hybrid Discipline}

Design is a concept full of purpose. In fact, this has been one of the key characteristics attributed to design in the ongoing discussion around a solid definition of what design is. Design serves a purpose. Design is motivated, not purely accidental. Design carries intention, to move from $A$ to $B$, from a given situation to a preferred one, from one future to another. Design enables. Design is useful.

A statement like "design is useful" of course rests on a rich historical narrative, with the Modernist movement, functionalism, Bauhaus, Utility Design, good design etc. Rather than accounting for the full historical trajectory of "usefulness" within the design discipline, this essay instead argues along 
a continuum ranging from the Industrial Revolution around 1800 up until the present. While design in one sense is as a deeply human activity that has existed since ancient times (Nelson \& Stolterman, 2012), the Industrial Revolution gave shape to the design discipline in its current state. Edging hard science, humanities and the arts, much time has been spent on articulating a design discourse, or in more design specific terms, to articulate "a designerly way of knowing" (Cross, 2007). Alongside this effort for a disciplinary consolidation and articulation, fields like business management, engineering, marketing and others continue to utilize design as a useful leveraging tool for making sense and profit.

Despite the fact that successful design in this applied sense sometimes comes across as a prescribed universal magic formula, design appears as a highly dynamic, contextual endeavor from within. Located in-between an ever-shifting landscape of economical, technological and social driving forces, design is in a constant state of iteration, exploration and maturation in the search for new answers and questions.

\section{Quantification \& Acceleration}

Design is not only subject to time, it actively utilizes and navigates it. From design subdisciplines such as interaction design or fashion design that relies on temporality as a key element, to what industrial designer Brook Stevens termed "planned obsolescence" already back in 1964 (Adamson, 2003). Planned obsolescence has since been used frequently in different contexts and discussions. In this essay the term refers to design artifacts (artifact understood in the widest possible sense) with life cycles carefully attuned to the yearly product release spectacles and the continuous feed of tech innovation, thus falling apart or otherwise digressing into the realm of obsolescence at the perfect(ly designed) time. This mechanism allows the user to have a temporally limited, yet satisfying product experience, ultimately resulting in a desire to buy a newer edition: an upgrade.

While the neoliberalist growth economy creates a steady acceleration in the demand for "newness," design maintains its strive for usefulness. The usefulness promised by the design artifact often

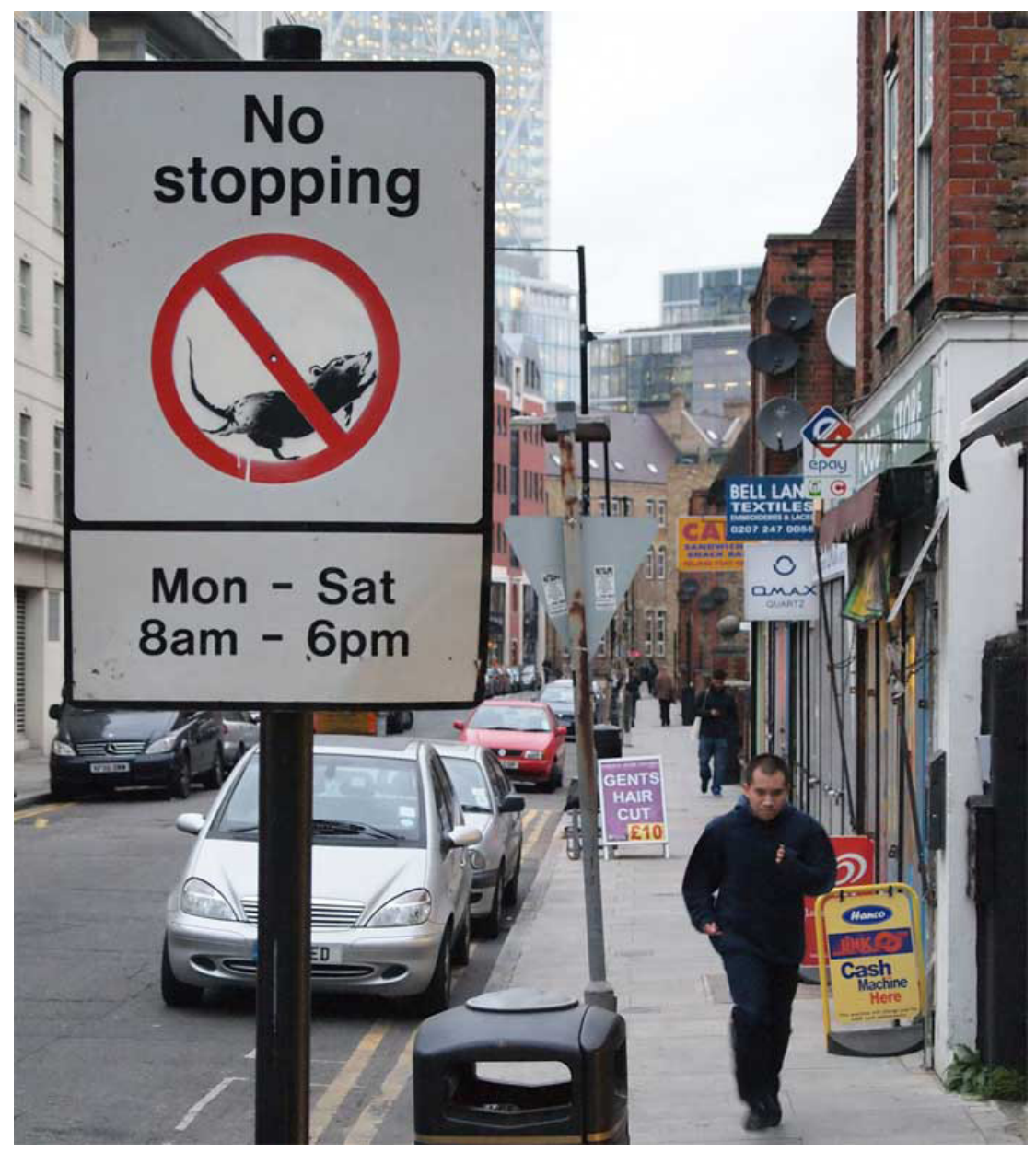

Figure 2. Banksy: No Stopping in the Rat Race. Photo by Duncan Hull, 2012. 


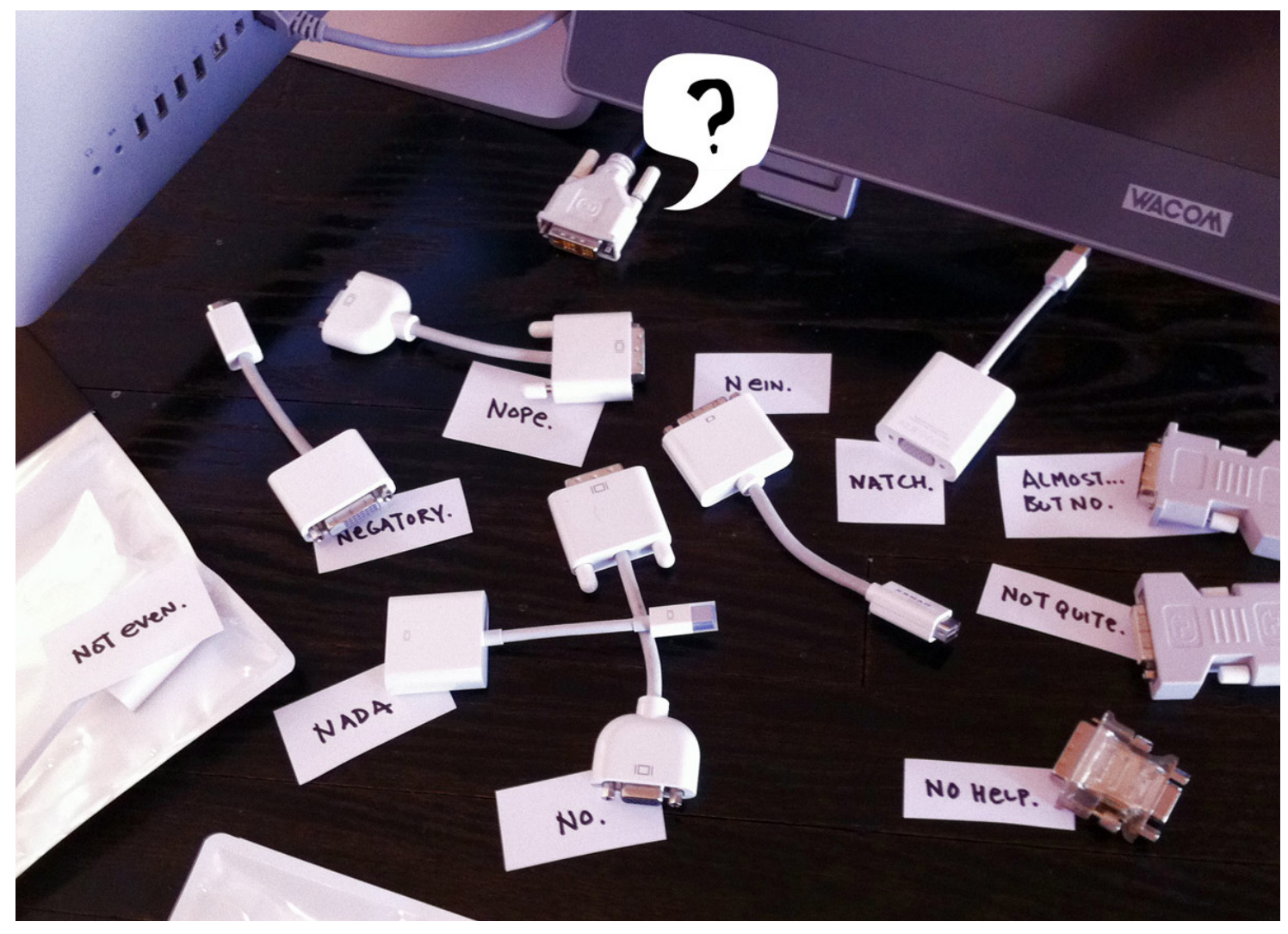

Figure 3. Tobias Lunchbreath: The SemiAnnual Adapter Parade, 2011

co-accelerates with the need for faster economic returns as continuous design improvements result in new functionality, a new look etc., being $3 \mathrm{~mm}$ slimmer, having 4 hours longer battery life, receiving 2 more sustainability certificates and so on. While one possible umbrella term for all these continuous improvements could be qualities, this focus would obscure the fact that these qualities too follow a market-driven need for quantification. As noted by author and collaborative design strategist Ann Thorpe, one of the key problems with the neoliberal market is the lack of valuation beyond monetary means:

It is now widely understood that the market and its financial or capital resources (for example, money, buildings or equipment) sit within a much wider economy made up of ecological and social resources. A key problem is that the market doesn't adequately account for the value of these resources or the damages to them that occur from pressures for economic growth. Prices don't reflect these values and damages. (Thorpe, 2013, p. 42)

In other words: any considerations for social value, sustainability, etc., gets instantly nullified in a $20 \%$ flash sale.
It is very hard to think of a design artifact that is not intended to be useful on some level. Useful extends the immediate quality "of having use" in the further unpacking of the word: being "full of use." With a design artifact like the iPhone (made by Apple, a company argued to be one of the most prominent and controversial companies to perfect planned obsolescence (Rampell, 2013)), e.g., you can surf the web, make a call, check your emails, make use of a million different applications, take pictures, record voice memos, play games, etc. All of this is packed into a convenient, carefully constructed form, fitting neatly into your pocket, allowing you to carry it around at all times. The device is evidently full of use. Extending the immediate physical qualities it emanates an Apple brand, carefully projecting certain values and sociocultural codes unto its user. It even smells of Apple.

\section{Conflicting Use}

Zooming out from this incomplete account of immediate usefulness packed into the design artifact itself, let us consider something like the global surveillance disclosures brought to light by NSA whistleblower Edward Snowden since 2013. ${ }^{1}$ In this respect the iPhone, like any smartphone, is incredibly useful in the way it allows intelligence agencies 
to track its owner using GPS combined with various metadata. Thus, it becomes a highly useful tracking tool. In his role as photographer and freelance journalist as well as developer and security researcher at The Tor Project, Jacob Appelbaum frames this particular dualism as the trade-off in security over greater convenience. He goes as far as stating that every time something becomes more convenient it is highly likely that it becomes less safe (Appelbaum, 2014). The fundamental conflict in use and desire illustrated through this dynamic helps us frame the first basic problem in the relationship between design and usefulness: useful means useful for whom?

This is, of course, not a clear-cut distinction. In the case of planned obsolescence, it is possible to imagine that a sudden (designed) breakdown of a design artifact is useful for both the manufacturer and the user. It might even be a relief: while the timely breakdown allows the manufacturer to sustain the momentum in the company's production pipeline (and thus keeping the economic growth rate steady), the user is relieved of any conflicting emotions between a mainstream sustainable argument against throwing away a device that works perfectly fine and the guilt-ridden insatiable desire for acquiring a new, better, shinier upgrade. While at first glance this situation might seem a convenient compromise for both parties, it still doesn't result in a truly useful design solution for everyone, as is evident when considering "stakeholder groups" like environmental activists and the people engaged in the unregulated mining of cassiterite (mobile phones etc.) in the Democratic Republic of the Congo, mica (cosmetics etc.) in India, etc.

Modern day market dynamics ensure that these massive conflicts between the various perceptions of usefulness are siloed into different societal realities. This is brilliantly illustrated in the documentary Blood in the Mobile (Beetz et al., 2010) where director Frank Poulsen sets out to expose the connection between our consumption of cell phones and the horrifying war in DR Congo. As it turns out, no Western phone manufacturer can guarantee that their minerals are not conflict minerals fuelling the war in DR Congo. After having successfully accessed and documented the illegal Bisie tin mine in DR Congo, Poulsen returns to Finnish headquarters of Nokia, the (then) biggest phone company in the world, finding himself facing a corporate monolith of glass, steel and silence. Another famous example of this front end/back end consumption/production logic is the popular referral to the Szenchen region in Southern China's Guangdong Province as "the factory of the world." One recalls William Gibson's famous quote about the future already being here, just not evenly distributed. It is tempting to draw a parallel stating that: usefulness is already here -it is just not evenly distributed.

Currently, even the supposedly "clean and perfect" solutions like cradle-to-cradle and conflict-free minerals are only useful from certain perspectives. Against the big promises these concepts deliver in theory, they tend to appear partly flawed in practice (Kera, 2014). When solutions like these are only available and beneficial for a certain group of companies that can afford to invest in a costly certification, is it then meaningful to talk of them as truly useful in a more normative, societal sense? Is it possible for certifications like these to be truly useful without full transparency in all aspects? Going back to the possibility of conflicting usefulness, it is further worth considering who benefits from a project like conflict-free minerals, or in other words, who it is useful for? For the companies that-perhaps due to investments, lobbying, nepotism, historical circumstances, luck, etc. - can gain an advantage in the market, for consumers who want to actively purchase conflict-free minerals, for politicians, for the people mining the minerals, for the planet?

The possible issues with these kinds of initiatives illustrate how the disruptive aspirations towards alternative societal constructs such as a circular economy ultimately find themselves trapped within the prevailing neoliberalist apparatus. As a consequence of an increasingly globalized world, the contextual relativity regarding what is useful and useless becomes crucial. The dramatic global rise in economic inequality stresses this point even further. As reported by Oxfam (2013) we have now reached a point where the 85 richest people on the planet own as much as the poorest half of the entire world population. If anything, this development towards an ever-greater economic divide stresses the importance of considering conflicting use. The deepening divide also brings us to the question of temporality in relation to usefulness.

\section{Temporality}

A design artifact reaches a point where the user decides that it is simply "used up": a curious term reflecting drainage of functionality, desire and attention. However, one use/user replaces another, as the piles of tech-rubble burning away on the African plains remind us. This long process of trickling-down through society is documented in the sheer abundance of terms describing temporality of use within our language: "misuse," DIY culture, second-hand, recycling, downcycling, upcycling, 


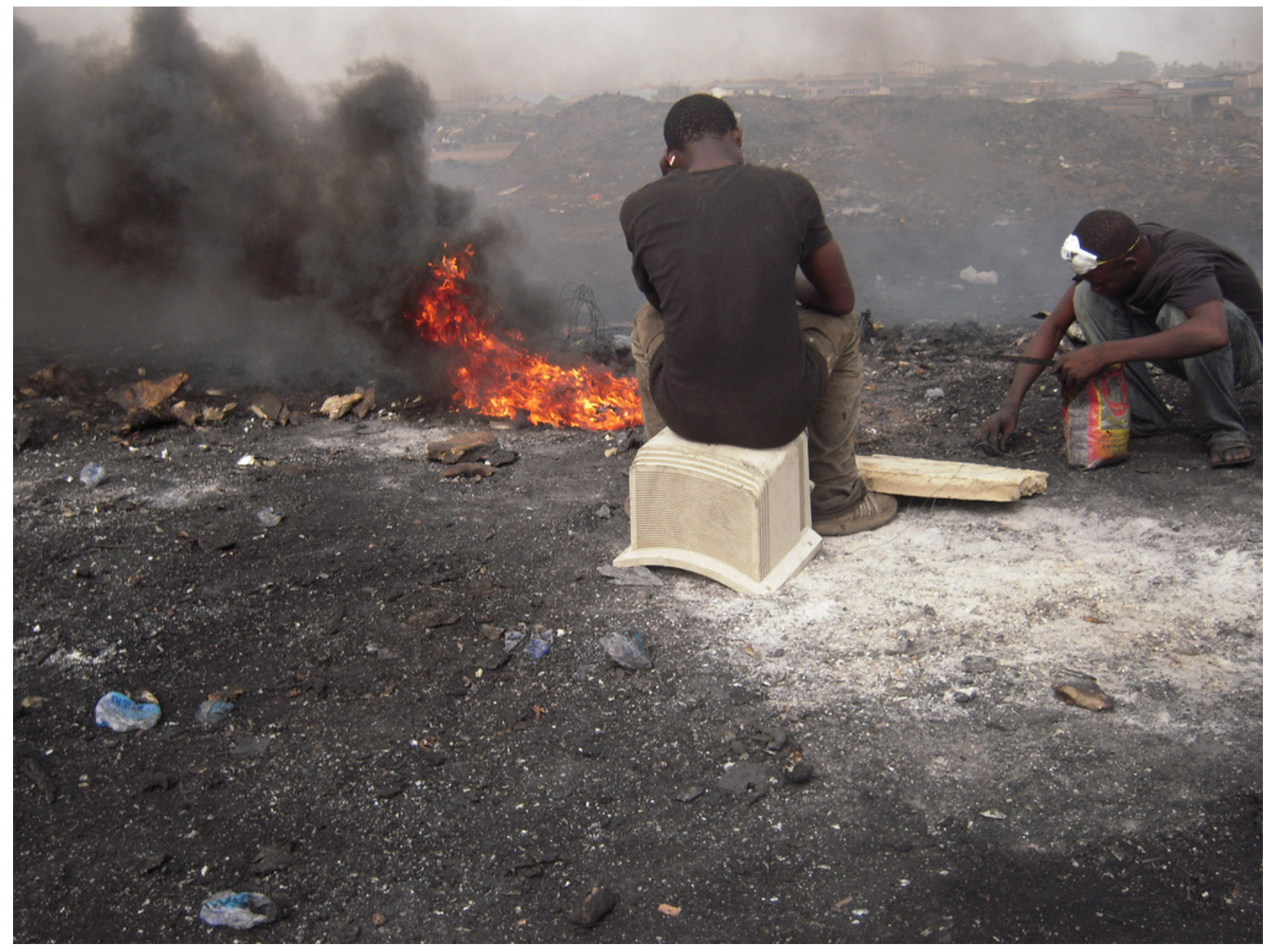

Figure 4. Pure Earth/Blacksmith Institute: Agbogbloshie e-Wasteland in Ghana, 2010.

remixing, hacking, bricolage, found objects, the new aesthetic etc. A fluctuating shift between use/user permeates all this. The design artifact often exits (or exceeds) its design intention as well as its supposed usefulness to live on in a cacophony of re-appropriation, promise and perhaps newfound appreciation, inhabiting a state of design after design (Redström, 2008) until it inevitably ends up as pure matter: ash, earth, metals etc., hopefully fertile, potentially toxic.

In this wider sense the temporary noise, emotion and agency in the flow of use is dwarfed into a mere blip on the vast timeline of our planet. Although limited to a certain number of years of time, this blip is however so substantial that scientists have proposed a new geological epoch in the history of the Earth denoting the period from the Industrial Revolution around 1800 to our current day, namely The Anthropocene, an era defined by the human imprint on the planet. Tying this current era back into the neoliberal society, Brazilian journalist and author Denis Russo Burgierman notes:
Designers (...) invent useful things. And useful things (...) are things that have a market value. According to this logic, design is undergoing a golden age. Never before in our planet's history have so many useful things been available at such low cost. (Burgierman, 2011)

He reaches this conclusion from the story of José Claudio Ribeiro Claudia (also known as Zé Cláudio) and his wife Maria do Espírito, who dedicated their lives to protecting and conserving the Amazon forest. The couple had a garden containing several Brazilian nut trees, a Southern American tree species generally known to live around 500 years, although trees older than 1000 years of age have been recorded. Burgierman illustrates the Anthropocene through this very tree, as the short-term financial incentives for logging it and keeping the iron-melting furnaces ablaze overrules the long-lasting flow of benefits, such as the Brazilian nut, which can be used for preventing certain types of cancer and heart disease. The conflict between the accelerating need for firewood and Zé Cláudio and Maria do 
Espírito's resistance tragically concluded with their assassination. It seems clear that they were not only up against the local loggers, but an entire system that for different, yet interconnected reasons had an interest in the continuing short-term economic growth stemming from the deforestation. The disregard for any qualities or concerns that could compromise this sole objective solemnly echoes Thorpe's point concerning the neoliberal market's inability to acknowledge any value beyond the monetary domain. ${ }^{2}$

On a political level, usefulness extends into the technocratic arguments for making sensible, unavoidable decisions. A recent example could be the Troika - the European Commission, International Monetary Fund and European Central Bank-imposing its vast austerity measures as the logical answer to the severe economic crisis running through several EU member states. Beside the fact that austerity measures has a highly unsuccessful historical record (Blyth, 2013), it is striking how no large-scale ideological debate or public articulation of underlying values precede decisions like these, considering the drastic consequences and the number of human lives affected. By now we all understand that such a discussion is impossible in the face of the inescapable course of action. ${ }^{3}$
Usefulness carries an aura of this unavoidable, unquestionable decision. Stretched to its fullest extent, it threatens to slowly instill a static (market-driven) consensus, effectively ending politics and valuation. ${ }^{4}$ In a design context, a similar mechanism is currently at hand with "useful design" effectively rendering "useless design" meaningless.

\section{PART II \\ Useless as the False Negation of Useful}

On the surface, "useless" appears to be the logic negation of "useful." If the latter expands into being "full of use" it seems tempting to suggest that "useless" accordingly translates into being "less of use," while in fact it conveys being "of no use" (Redström, 2011). A useless artifact presents no use to us. It promises nothing. It has failed us. Contrasting the abundance and potential plurality of uses expressed in being "full of use," uselessness is a static zero, a singular rejection. Importantly, this doesn't mean that useless is the logic negation of useful. Unlike black/white or on/off they are rather two intimately related, yet ambiguous concepts. To examine this further, let us ask ourselves why useful is desirable in the first place? This clearly becomes a question of valuation. Why do we need the distinction useful/ useless at all? Why not talk about desirable/undesirable? Meaningful/meaningless? Constructive/ destructive? Sustainable/unsustainable? Critical/

Figure 5. The EU and Greek flags flying over the Acropolis: testimony to the influence of international capital on the fate of individual countries. Photo by Angelos Tzortzinis (Bloomberg via Getty Images)

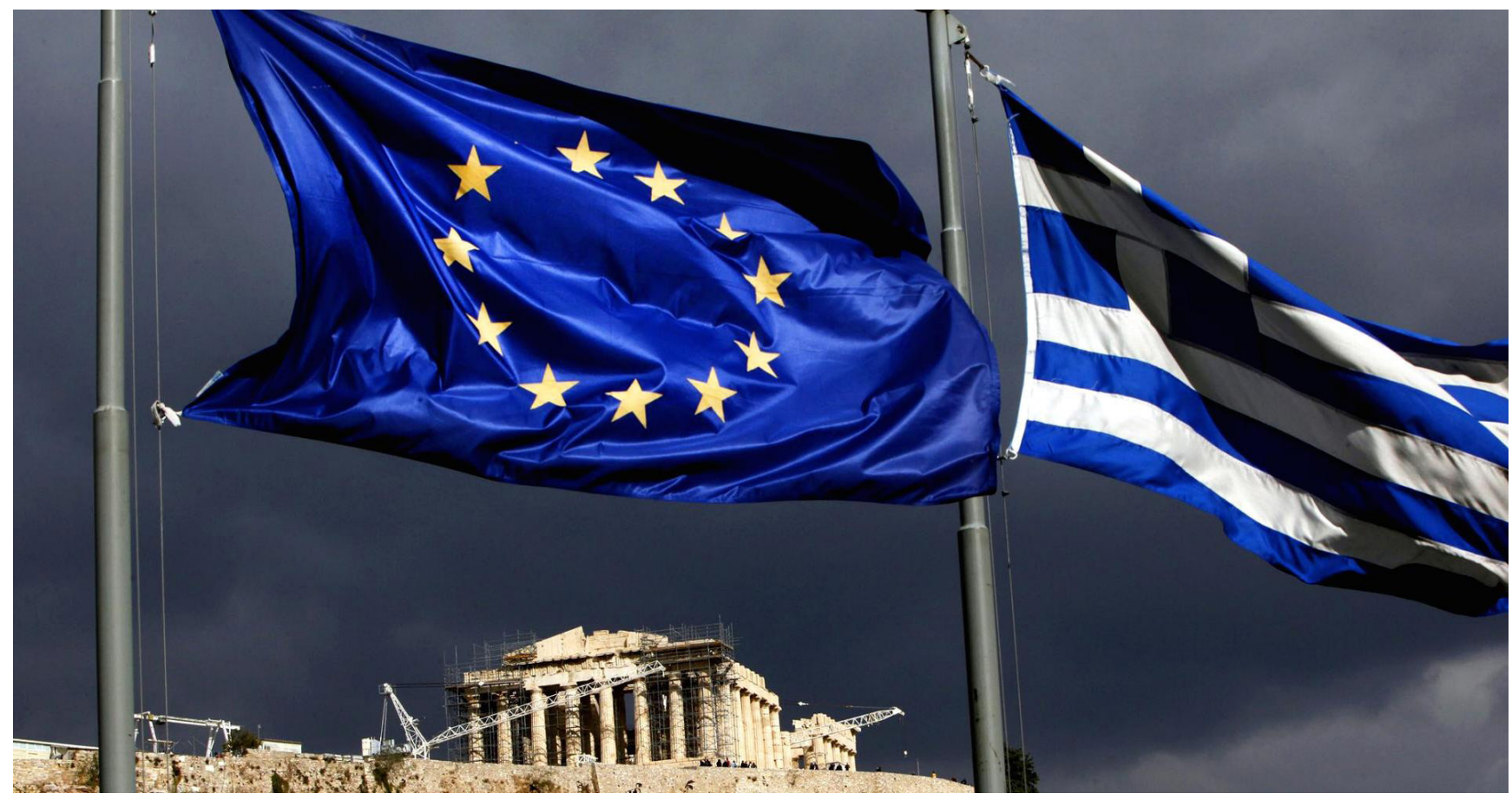


conformist? A brief return to the rich design historical narrative underlying the notion of "usefulness" provides us with an appropriate point of departure for exploring these dichotomies further. As Harold Nelson and Erik Stolterman note regarding the historical dominance of the scientific method in the Western world:

Over time, many different ways of conducting inquiry into what can confidently be considered to be true have been "designed" as opposed to being inherently obvious. These differing forms of inquiry have been sufficiently successful-in the right context, and at certain moments in history-to be championed as superior forms of inquiry, regardless of the situation or need. This is especially true of inquiry based on the scientific method. (Nelson \& Stolterman, 2012, p. 32-33)

Fast forward from the historical designation of the scientific method in the Western world to the increasingly complex relationship we have with our intelligent technology today. Alongside this accelerating development, a critical discourse within design has gained traction over the last decades, articulating the darker aspects of the increasingly complex human-tech relationships through a speculative, imaginative design vocabulary. Dunne and Raby have been key figures in establishing and articulating first critical and later speculative design. In their formulation of a critical design agenda, they draw up their own in $A / B, A$ Manifesto (2009). Whereas " $A$ " is sketching the conformist society (affirmative, business-as-usual, consumption-obsessed, one-dimensional), " $B$ " is presenting us with the antithesis that formulates Dunne and Raby's speculative design project. By investigating the particular dichotomy represented by Dunne and Raby's $A / B$, we might be able to shed some light on the useful/useless counterpart.

When examining $A / B, A$ Manifesto, a certain set of values emerge in the consistent tension between $A$ and B. For instance, "in the service of industry" vs. "in the service of society" tells us something about the point of view, namely that of society. "Change the world to suit us" vs. "change us to suit the world" goes on to relate society to the world in which it exists, taking a somewhat humble position against anthropocentrism. A power relation is hereby identified. "Consumer" vs. "citizen" presents us with an active societal stand against consumerism while also conveying values such as civil agency and perhaps ability and possibility to act within society. "Makes us buy" vs. "makes us think" points to reflection, envisioning, questioning and ethics.
These qualities are extended manifold in "for how the world is" vs. "for how the world could be," "futures" vs. "parallel words" and "fictional functions" vs. "functional fictions."

\begin{tabular}{|c|c|}
\hline$(a)$ & $(b)$ \\
\hline affirmative & critical \\
\hline problem solving & problem finding \\
\hline design as process & design as medium \\
\hline provides answers & asks questions \\
\hline $\begin{array}{l}\text { in the service of industry } \\
\text { for how the world is }\end{array}$ & $\begin{array}{l}\text { in the service of society } \\
\text { for how the world could be }\end{array}$ \\
\hline science fiction & social fiction \\
\hline futures & parallel worlds \\
\hline fictional functions & functional fictions \\
\hline $\begin{array}{l}\text { change the world to suit us } \\
\text { narratives of production } \\
\text { anti-art }\end{array}$ & $\begin{array}{l}\text { change us to suit the world } \\
\text { narratives of consumption } \\
\text { applied art }\end{array}$ \\
\hline research for design & research through design \\
\hline applications & implications \\
\hline design for production & design for debate \\
\hline fun & satire \\
\hline concept design & conceptual design \\
\hline consumer & citizen \\
\hline user & person \\
\hline training & education \\
\hline makes us buy & makes us think \\
\hline innovation & provocation \\
\hline ergonomics & rhetoric \\
\hline
\end{tabular}

Figure 6. Dunne \& Raby: $A / B, A$ Manifesto, 2009.

Seeing as $A / B, A$ Manifesto is already a distillation of a complex set of evolving ideas, a further summarization as the one sketched out above is bound to fail in terms of capturing the richness and nuances within the broader field of speculative and critical design. That said, it is clear that the field displays a predominant set of values. Arguably, one of the best ways to tell if a particular position has certain values embedded lies in the ability to effectively question and thereby counter them, as happened recently in a public discussion on MoMA's Design \& Violence website (Thackara, 2013). While a full report of the discussion is too extensive for this context, the fact that the discussion took place in an online public forum stands as testimony to the existence of certain values that it was possible to openly bring into question.

Importantly, $A / B, A$ Manifesto is only one example of how design already engages with some of the alternative dichotomies sketched out in the beginning of this paragraph. It would indeed be valuable to analyze some of the alternatives further as well. The value in bringing this particular example to the fore at this point lies in the tension between its 


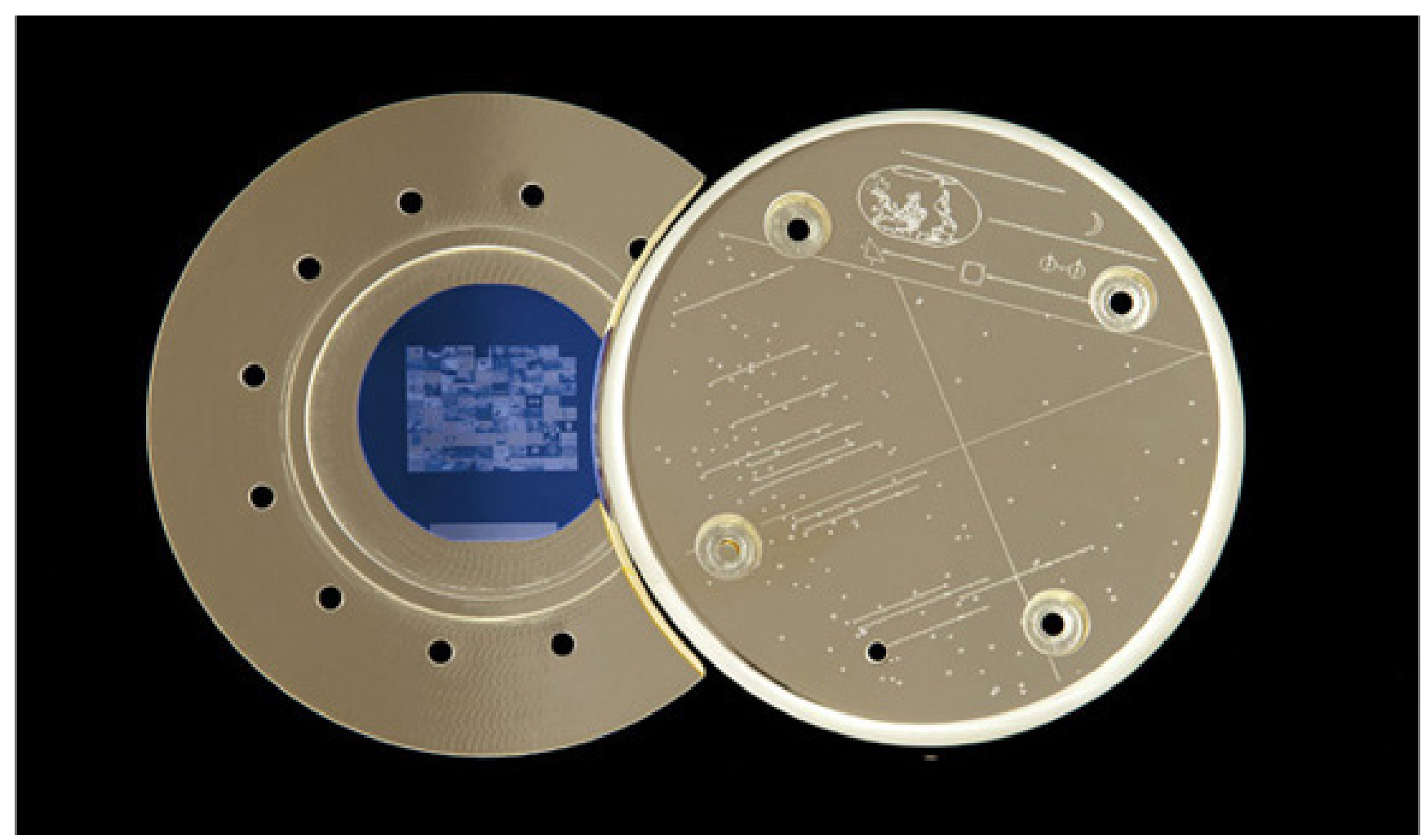

Figure 7. Trevor Paglen: The Last Pictures, 2012.

schematic and conscious self-positioning through the $A / B$ dichotomy vs. the persisting, larger debate concerning the validity of this very positioning (e.g. theoretical grounding (Bardzell \& Bardzell, 2013), feminism (Prado de 0. Martins, 2014) and Eurocentrism, orthodoxy and naïvity (Gonzatto et al., 2013). As we shall soon discover a similar kind of "discursive (de)construct(ion)" exists within the useless vs. useful.

But let us now take a brief trip into the future and explore the ambiguous relation between useless and useful further through yet another speculative and critical design format: design fictions.

\section{Useful and Useless Futures}

To reiterate, precious attention span, time and enormous (limited!) resources are pouring into seemingly useful design artifacts, delivering and performing until they are used up at the horizon of a linear one-dimensional foreseeable future. Let us recall the altered Gibson quote (usefulness is already here-it is just not evenly distributed) as we move into a few of these useful and useless futures.

Starting on the useful end of the spectrum, future studies or futurology such as "Microsoft Office Labs vision 2019," depicts the useful future in full HD. This is a story about how future tech fixes our problems of today. In essence it is a depiction of a future with no changes beyond new gadgets, a slightly better resolution and more RAM (Gonzatto et al., 2013). Similarly, in the construction of Songhdo International Business District in Seoul, South Korea, Cisco paints the following picture of the smart city of the future:

According to $A B I$ research $\$ 39,5$ billion is projected to be spent on smart city technologies in 2016. From public transportation to shopping, the city of the future has the potential to significantly transform urban living-and might be closer than we think. (Cisco Visualizations, 2014)

In the minuscule spectrum between public transportation (get to work fast = produce) and shopping (spend all your money = consume) resides usefulness. This is the timeless cradle of usefulness, past, present and future. In the case of Cisco we are presented with a promise of a bright, profitable, intelligent future, built by huge investments and with promises of even bigger returns. One dares to ask where the human resides in this calculation? 
Set against Cisco's vision for life on Earth anno 2016, The Last Pictures by American artist and author Trevor Paglen deals with anthropocentrism and the scale of time in a radically different way. In collaboration with scientists at the MIT, Paglen designed a micro-etched disc containing 100 carefully selected pictures encapsulating life on Earth anno 2012, mounted it unto a satellite and sent it out on its journey, destined to join the belt of ghost satellites drifting in the geosynchronous orbit around Earth approximately $36,000 \mathrm{~km}$ out into space. As a contained snapshot of life on Earth anno 2012, The Last Pictures follows a tradition of actively attempting to communicate with potential alien life in space, Carl Sagan's Pioneer Plaque from 1972 perhaps being one of its most famous precursors. Unlike back then, Paglen openly states that he doesn't believe extraterrestrials will ever find the Golden LP in which the micro-etched disc is secured from billions of years of wear and tear. Rather:

I believe in continually asking the questions that designing for extraterrestrials implies, because thinking about aliens is a way to think about ourselves and our relationship to the future. The impossible questions of representation and form are fruitful to consider. I do not think that the Golden LP holds anything more than provisional, deeply flawed solutions. I do not think that there are any solutions. There cannot be. But that does not mean that these insoluble questions are ones that we should ignore. Symbolically, much is at stake.
Underlying the question of how to consider aliens is a deeply ethical question, namely what relationship do we want to have to the cosmos, to the stranger and to the future? (Paglen, 2013)

Abandoning the sci-fi vision of establishing (useful) contact with alien life forms, The Last Pictures instead bridges our present and future by orbiting into a future state of perpetual uselessness while facilitating an important, urgent and useful discussion of how we understand our present selves.

\section{The Unuseless \& The Unfindable}

Within the false dichotomy between uselessness vs. usefulness, it is as if the flawed rationale behind "useful design" mirrors a certain absurd, perhaps even surreal quality unto "useless design."

The art of chindōgu is an interesting concept to consider in this respect. Chindōgu, vaguely translating to "really weird tools" in English (Papia, n.d.), is a Japanese concept of almost useless designs, or as the "Japanese gadget guru extraordinaire and anarchic progenitor of chindōgu" (Hornyak, 2002) Kenji Kawakeni interestingly characterizes it: "unuseless." Developed in the 1980s by Kawakeni, chindōgu got highly popular in Japan and abroad with the International Chindōgu Society existing to this day.

The 10 tenets constituting chindōgu read:

Figure 8. Kenji Kawakami \& Dan Papia: Shoe Umbrellas (from 101 Unuseless Japanese Inventions, 1995).

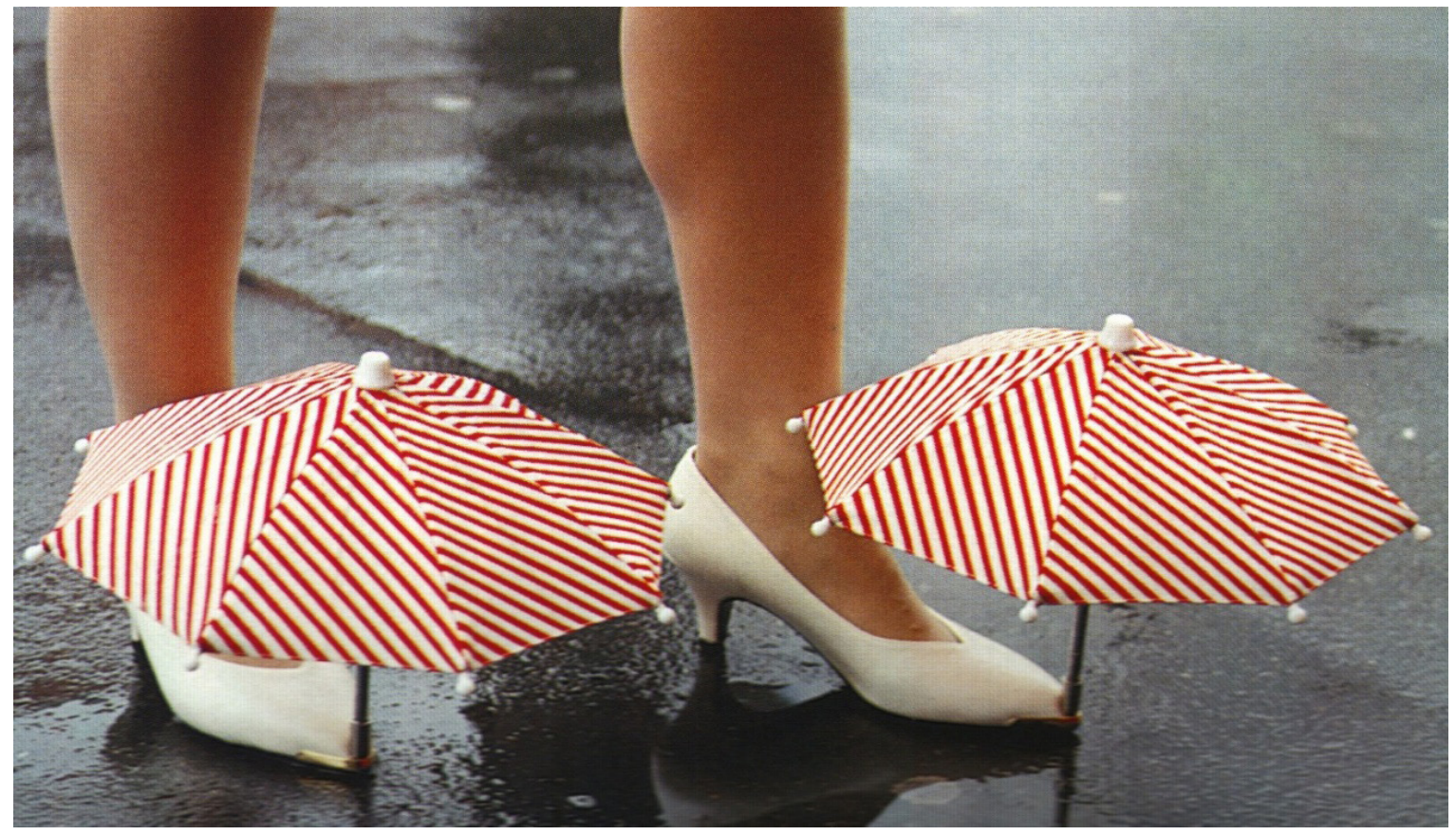


1. A chindōgu cannot be for real use

2. A chindōgu must exist

3. Inherent in every chindōgu is the spirit of anarchy

4. Chindōgu are tools for everyday life

5. Chindōgu are not for sale

6 . Humour must not be the sole reason for creating a chindōgu

7. Chindōgu is not propaganda

8. Chindōgu are never taboo

9. Chindōgu cannot be patented

10. Chindōgu are without prejudice

(The Ten Chindogu Tenets, n.d.)

In the context of this essay tenet 3 is particularly interesting:

Chindōgu are man-made objects that have broken free from the chains of usefulness. They represent freedom of thought and action: the freedom to challenge the suffocating historical dominance of conservative utility; the freedom to be (almost) useless. (The Ten Chindogu Tenets, n.d.)
Chindōgu is an interesting example of a conscious, playful positioning within the grey distorted space in-between the useless and the useful. In a sense it is as if the chindōgu solution trips in the sheer abundance and exhilaration of Western usefulness, arriving at an absurd, ridiculous position that however fails to render the invention technically useless (as in literally "of no use"), hence arriving at "un-useless." Further, Kawakeni talks of chindōgu as "invention dropouts" (Hornyak, 2002), making a historical link between chindōgu and the Industrial Revolution in Great Britain. In this comparison he makes a distinction between how usual products become ever more convenient whereas each chindōgu carries bigger disadvantages than its precursor (recalling Appelbaum's trade-off in security over convenience). In summary, chindōgu thereby positions itself not only against usefulness but also consumer culture, politics and the digital.

Chindōgu has a related French precursor in painter, illustrator and designer etc. Jacques Carelman's Catalogue d'objets introuvables, literally translating into Catalogue of unfindable objects (Carelman, 1984) although different translations exist in English. Interestingly, while Carelman was parodying the catalogue of the French mail-order company Manufrance, Kawakeni was developing chindōgu in the 1980s while editing home shopping magazine Tsuhan Seikatsu. Through this lens it makes sense to talk of a certain critique of the "useful design logic" across Carelman's unfindable objects and
Figure 9. The Catalogue d'objets introuvables. Retrieved 16 December, 2014, from http://impossibleobjects.com/

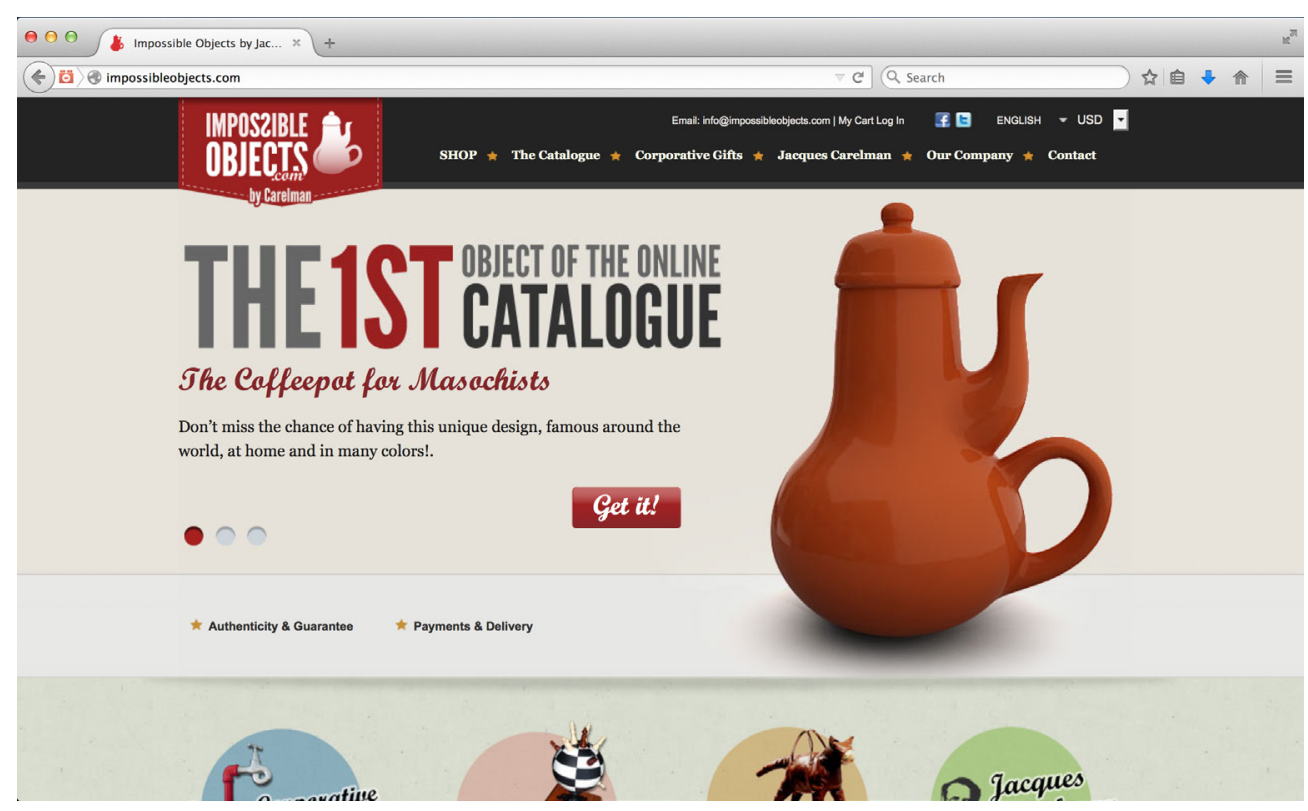


Kawakeni's chindōgu, perhaps even a critique of consumer culture itself (notice how the mail-order catalogue and home shopping magazine act as convenient interfaces between the aforementioned front/back end division). Thus, Carelman and Kawakeni's works illustrate the absurd and humorous qualities within one particular understanding of useless design, a sort of nonsensical "useful overdrive."

\section{The Risk of Assimilation, Fetishization \& The Spectacle}

One of the risks in this framing of "useless" lies in mainstream consumer culture's extraordinary ability to assimilate, utilize and monetize even absurd and critical exaggerations like these. In the case of Carelman, the all too familiar mechanism is manifested in the site http://impossibleobjects. com/, holding the "exclusive rights to reproduce to scale and sell the works of the Catalogue d'Objets Introuvables created by Jacques Carelman" (http://impossibleobjects.com/). Similarly, chindōgu has produced several best-selling books over the years, such as 101 Unuseless Japanese Inventions (Kawakeni \& Papia, 1995), the sequel 99 More Unuseless Japanese Inventions (Kawakeni \& Papia, 1997) and more. Chindogu has further been featured on It'll Never Work, a BBC science show for kids. While this commercialization does not in any way diminish the merits of either concept, it points out how usefulness through consumption successfully holds the ability to deteriorate the un-useful into an amusing integral spectacle within the consumer culture. This is essentially the same mechanism we encountered earlier with the disruptive aspirations towards a cyclical economy ultimately getting trapped within the prevailing neoliberalist apparatus.

Following this idea of the spectacle, I would argue that a society pervaded by usefulness exhibits a certain defensive tendency to fetishize and elevate any artifact that simply hints at the mere possibility of a (useless) alternative. One can think of a celebrated example like Philippe Stark's controversial Juicy Saliflemon squeezer. When one of the contemporary star designers can stir up such levels of craze over a kitchenware design artifact by making such slight divergence from the celebrated "form follows function" industrial design credo, one begins to understand why a business model like http:// impossibleobjects.com/ exists in the first place. Of course, rather than measuring the success of the Juicy Salif based on how well it is able to squeeze citrus fruits into delicious fruit juice, other qualities take precedence: aesthetic pleasure, weight, grip, social status, social interaction etc. For all we know, the Juicy Salif could be a useful door wedge or tennis trophy. While the Juicy Salif also might attract so much attention simply by being a (star) design artifact by Philippe Starck, the fetishization and spectacle exist as a general latent phenomenon pervading the iconic design pieces as well as the everyday in a society championing usefulness. Through assimilation, these mechanisms are threatening to detach any concept of "useless design" further from any mainstream realization.

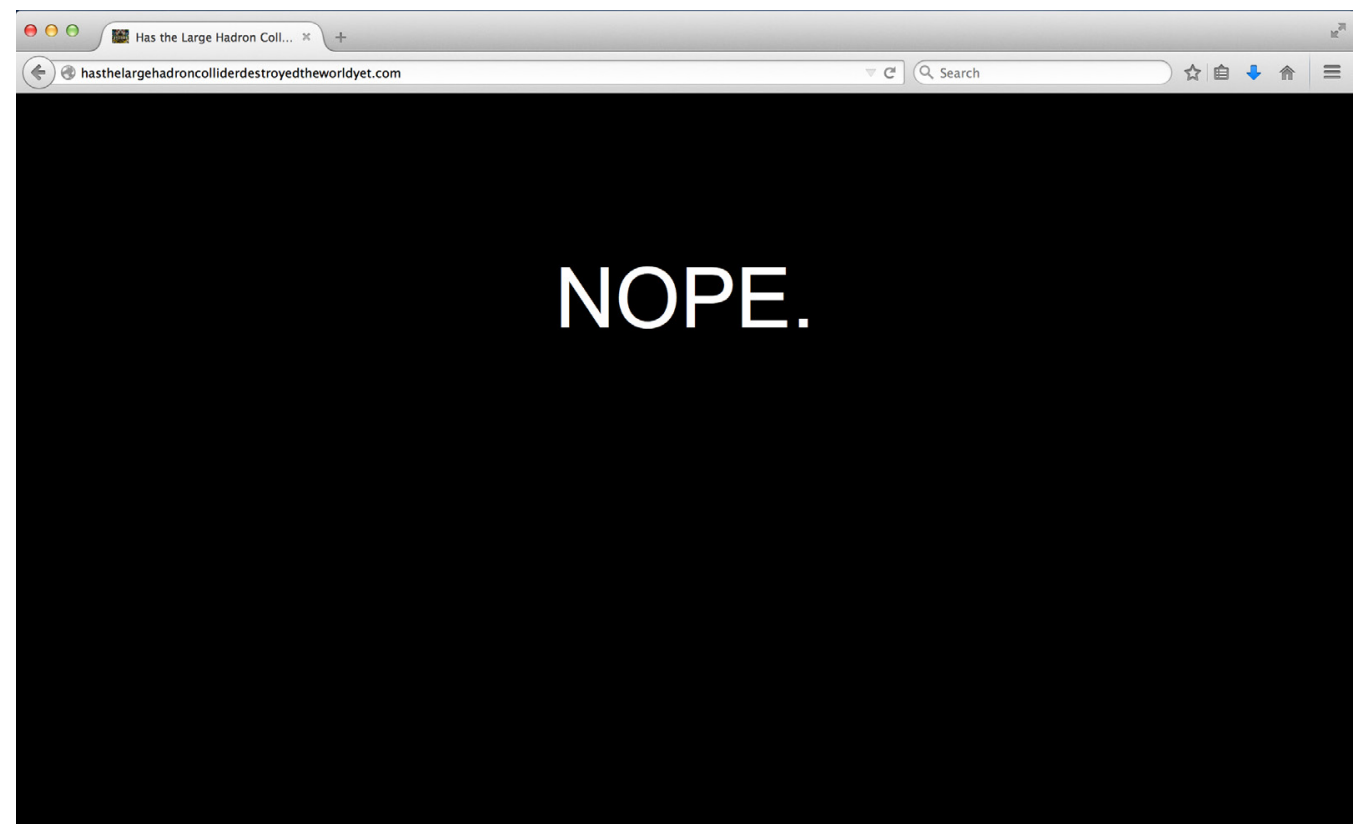

Figure 10. Has the Large Hadron Collider destroyed the world yet [web site]. Viewing the site's source code reveals the additional message: "if the Ihc actually destroys the earth \& this page isn't yet updated, please email mike@frantic.org<mailto:mike@frantic.org>to receive a full refund." Retrieved 16 December, 2014, from http://www. hasthelargehadroncolliderdestroyedtheworldyet. com/. 
Take Me to Another Useless Website, Please

Turning towards the concept of "useless design" in the digital domain, let's consider the website, or perhaps more accurately, the generator of websites: http://www.theuselessweb.com/. Entering this website, the user is met with a button containing the following text: "TAKE ME TO ANOTHER USELESS WEBSITE, PLEASE." Clicking the "PLEASE" button simply opens a new browser window with a random "useless website" ("useless" as promised by the Useless Web). Examples of the rather large pools of randomly generated websites include:

\section{- http://ducksarethebest.com/}

A background fading aggressively through different bright hues, with your pointer leaving a string of pixelated rubber ducks behind as you move it around the site.

- http://www.pleaselike.com/

A minimalistic empty site with a single tiny embedded Facebook "like" button as the only visible content.

- http://www.pointerpointer.com/

A black site with an outlined box invites you to place the pointer inside it. After locating the pointer, the box shows a photo with someone in the picture pointing straight to the pointer, millimeters away on the screen. Moving the pointer ever so slightly reactivates the black box and a new photo is shown after a new location of the pointer. The photos appear extremely random, although the style is predominantly within the "genre" of Western party photography.

- http://hasthelargehadroncolliderdestroyedtheworldyet. $\underline{\mathrm{com} /}$

A black background with a white sans serif spelling out "NOPE."

\section{- http://www.leekspin.com/}

A looped manga animation with a girl spinning a leek and singing endlessly. At the bottom is a timer reading "You've been spinning for $\mathrm{X}: \mathrm{XX:XX."}$

This is of course merely a tip of the useless iceberg that http://www.theuselessweb.com/ is capable of building in your browser. The present selection is done both to highlight the breadth and the commonalities across the various design artifacts in question.
One of the striking features of the useless websites is how most websites are interactive and playful. However, these qualities are achieved in several different ways, ranging from contemporary responsive programming, including tracking of cursor movement, animation with visuals and sound, etc., to a single embedded "like" button. With regard to web design and "form follows function," it is interesting to notice how all websites display an extremely high degree of contextual awareness. The form, in this case the web site format, subdues the content e.g. by posing post-ironic rhetorical questions, ranging from "http://hasthelargehadroncolliderdestroyedtheworldyet.com/? - NOPE." or "http:// www.ismycomputeron.com/ - YES.," etc.

A website like http://hasthelargehadroncolliderdestroyedtheworldyet.com/not only confronts us with the question whether the LHC is capable of destroying the world but also our reliance on the Internet as the real time go-to news source. Besides a catchysoon-to-become-annoying loop absurdity, http:// www.leekspin.com/ similarly offers the possibility of counting how many seconds, minutes or perhaps hours you have been "spinning leek," i.e., spending time online. I would argue that both examples in this sense offer a humorous, highly self-conscious meta-level of critique amidst the general splendor of Internet celebration (http://ducksarethebest.com/ is one of the more pure proponents of this ecstatic layer). This curious dualism perhaps offers a valuable insight into the complex nature of "useless."

By running through the seemingly never-ending pool of useless websites, two distinct groups of websites take shape. On one end we find the low-fi, perhaps somewhat nostalgic, deliberately minimalistic sites that seem to take pleasure in cramming up the world's servers with pixelated post-irony and white space. On the other end we find a more disparate group of progressive, absurd and playful websites offering three-dimensional surreal web experiences. I would argue that both ends of this spectrum effectively push our Western idea of what "a website" is and what it could be.

It is indeed worth remembering that the Internet originally was developed for the military. It is further no surprise that usefulness runs like a common thread through life online just as it does offline. Even though the Internet these days largely consists of standardized blog-shop-like interfaces out of concerns for usefulness, there is however a space beyond the one inhabited by the vast sea of cleancut templates. The Useless Web presents us with a taste of uselessness at either end of this spectrum. 


\section{PART III}

\section{What is Useless Design?}

Useless design holds a potential in re-claiming the design artifact as a tool for valuation.

Useless design resists the apathetic acceleration of economic growth for growth's sake.

Useless design is business-as-unusual.

Useless design is a tabula rasa in the sense that it exists beyond the false dichotomy between the useless and the useful.

Useless design is a fertile void that invites for new questions to be planted and nurtured.

\section{Why Do We Need Useless Design?}

When a design artifact is useless it is equally useless to everyone, in the sense that it acts as an invitation to negotiate value and meaning beyond monetary figures. Thus, in essence useless design is an invitation to make useful, here "useful" understood in reappropriated terms, beyond its currently one-dimensional, confined state.

From this understanding of useless design as an invitation to make useful let us make a brief return to Redström's notion of "design after design" (2008). In this context Redström goes on to discuss Hunt's "tactical formlessness" (2003) and Tonkinwise's (2005) "designing things that are not finished," arguing that the latter partly builds on Jones" (1984) concept of "pure design":

Although at first taken aback by the implications of 'art for art's sake' and 'uselessness', I have since found the term [pure design] helpful in revealing the possibility of a new kind of design that seems appropriate now: designing without purpose (or without a purpose that was fixed before the moment of use). And I see a precedent in the astonishing way languages arise and develop, purpose (meaning) of a word changing slightly each time it is 'used', used. This, I feel, is the kind of metaphor which is appropriate to designing 'at the scale of life.' (Jones, 1984 via Redström, 2008)

Indeed, all these different framings offer valuable reflections and insights highly relevant for a nascent useless design practice situated in a changing landscape of an emerging post-industrial design paradigm. From considering "design after design" in relation to the design artifact, we can change to a wider lens and think of this larger discursive and disciplinary shift quite literally in terms of a "design after industrial design."
In "A Manifesto for Postindustrial Design" from 2005, Hunt describes the turn from industrial to post-industrial society and draws out some of the unfolding implications for the design discipline. From analyzing a series of post-industrial design practices, he proposes the following post-industrial design characteristics: formless, free, metabolic, and decentralized. In making this analysis he stresses that: "Postindustrial design is not even one thing yet, but multiple, heterogeneous strains that are destabilizing the industrial mode of production" (Hunt, 2005). The manifesto can be read as a continuation of Cross' anticipation of a dawning paradigm shift within the design discipline in "The coming of post-industrial design" (Cross, 1981). Hunt's "Postindustrial Manifesto" reads as a welcome reminder of the disruptive practices that indeed continue to challenge the conservative industrial mode of production. That said it is interesting to note how a statement regarding computer coding like: "(...) you can always move back in time. Just undo it," (Hunt, 2005) has gotten a profoundly different ring in 2014 following the global surveillance disclosures by Snowden. Recalling the initial example of conflicting notions of usefulness in relation to the smartphone (calling device vs. surveillance device), the natural ability to undo strikes one as something we now realize might well be forever lost-that is if it has ever existed in the first place. In a larger societal sense, the lost ability to undo bears a strong resemblance to the political rhetoric revolving around the unavoidable, the necessary and the useful. This link is further emphasized in Internet artist and theorist, etc., Olia Lialina's online proposition regarding "The right to UNDO" (2013) as part of the online co-creation of a Bill of Computer Users Rights. Hunt is aware of this turbulence within the transition between the two paradigms, as he observes that "[in] this primordial ooze of mutating code, the industrial mode of production is just a rotting old carcass, decomposing but still taking up space."

The extent to which this decomposing carcass is capable of upholding itself is quite striking at times. Quite unlike the slow organic process of decomposing that can be observed in nature, the industrial machinery repels the post-industrial paradigm through historical dominance and power instrumentalized and manifested in the range of aforementioned tactics such as assimilation, commodification and fetishization. The resistance even extends into the future as the static human-less visions of Microsoft and Cisco illustrate.

The context for useless design to make useful is the disruption and constant clashes located within the chasm between these two currently co-existing 
paradigms. There is a huge need for reappropriating the notion of usefulness. As the increasing global societal divide between the ultra rich (front end consumption) and the ultra poor (back end production) deteriorates any remaining notions of what is actually useful for whom and when, it becomes crucial for design to help prototype new societal agendas and facilitate new discussions.

Thus, useless design becomes a critical vessel for traversing the turbulence and contestation in-between the industrial and the post-industrial. The value in useless design ultimately lies in its ability to valuate: articulate, refuse, critique, spark, turn, transgress, formulate, transform etc. Contrary to how the old useful rejected the useless, the useless now invites a new useful. This ability takes useless design beyond the current limits of the seemingly immutable use/consume design equilibrium. As every discussion, sketch or brief no longer finds its natural pivot point in an impossible system of ever-increasing monetary value, there is not only a room for having completely different discussions but also a need or even responsibility for design to articulate and give shape to this multitude of emerging foci. As Burgierman puts it:

Every designer must make a choice. He can live life as if nothing is happening and go on feeding into the current pattern of our civilization, which is based on exploiting nature's resources, to then transform them into useful things and sell those things to make money. Or he can try to apply this knowledge of design to create a new logic that replaces the present one. Instead of continuing to design things within the system, design a new system of making things. (Burgierman, 2011)

As illustrated in this essay, many design projects and concepts are already somehow engaged with useless design, although they might not identify themselves primarily as such, but rather as pure design, tactical formlessness, speculative design, critical design, design fiction, adversarial design, discursive design, sustainable design, design activism, the unuseless, the unfindable etc.

Rather than a trivial terminological icing, useless design offers a critical framing for a design practice that actively addresses the need for redesigning one of the very driving forces behind the discipline from its industrial inception till this day: the notion of usefulness.

I sincerely hope that this essay-in a hopefully useless manner-has provided a foundation unto which it is possible, and perhaps even interesting, to imagine, argue and design the useless. Through diverse examples of uselessness brought up across the many different instantiations of the design artifact (be it analog or digital, culinary or astronomical, a thousand years ago or half a decade ahead in time), several characteristics, tactics and qualities emerge and confluence. All these contribute towards the continuing and urgent need for prototyping a useless design practice.

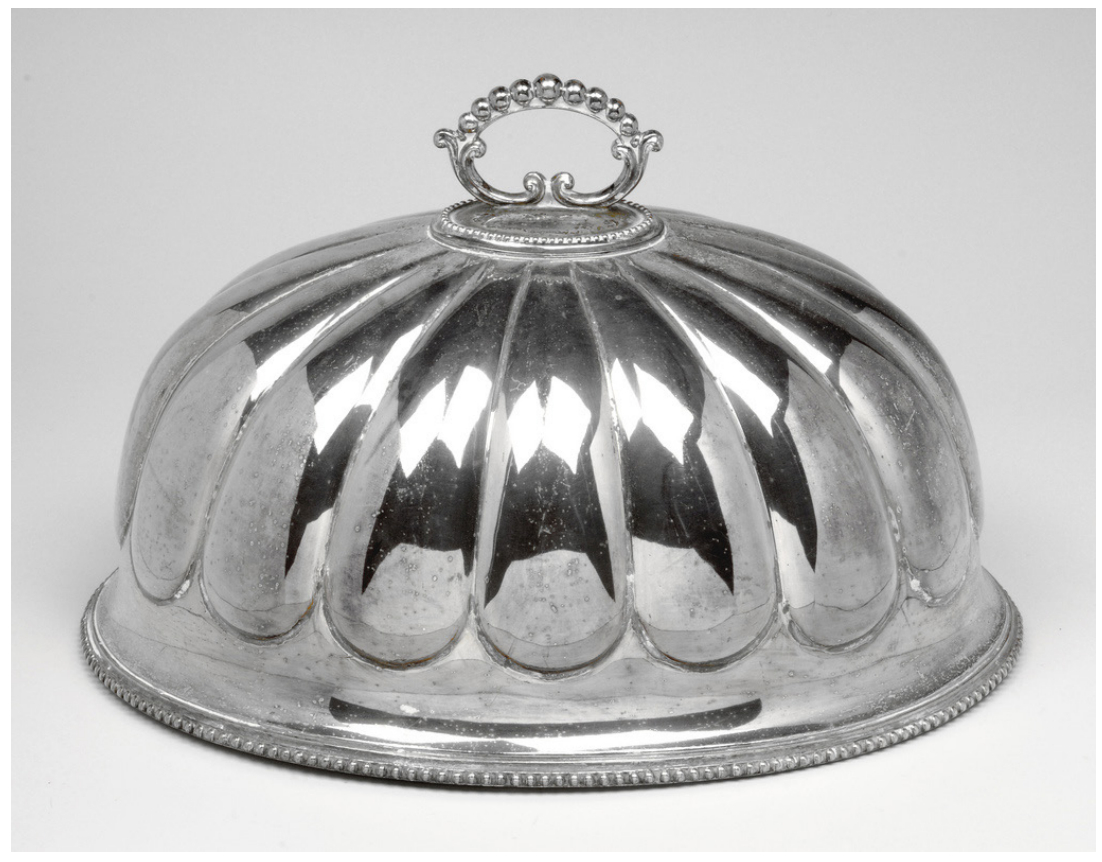

Figure 11. Useless design as the entremet that could shake the concept of "meal" entirely without leaving the guests hungry? Photo by Leeds Museums and Galleries, 2010. 
The final part of the essay will invite the reader to make this shift from the abstract to the concrete by sketching out a few ways that useless design could exist.

\section{How Could Useless Design Exist?}

Useless design as the single void canvas within the elaborate wayfinding system in the airport, guiding you from security through tax-free to your gate. How does it catch your attention outside the monotonous flow of signs fading in and out, all carefully aligned to the overall corporate design manual? What does this void look like? How does it make you feel? Where does it take your eyes and body next? Where do you end up going outside the world of terminal $A$, $\mathrm{B}, \mathrm{C}$, and "gates closing in 2 mins?"

Useless design as the island that exists beyond your map. A place well documented through countless conflicting tales and yet so incredibly absent within the grid laid out in front of you. A place in place of the casual blue gradients that illustrate an imaginary, perfectly still ocean. A place available for anyone to visit, occupy, modify, inhabit and leave. At least that much is agreed upon. What do you do faced with this simultaneous rejection of somewhere and invitation to elsewhere?

Useless design as the lemon sorbet "entremet" served in-between meals at some fancy restaurant to clean the taste palate before yet another exquisite, beautifully designed dish is put on the table. As the waiter lifts the shiny cloche, what could replace that lemon sorbet; the look, smell, taste, etc.? What could replace its immediate context; the waiter's inability to explain anything about what is being served, the sudden nullification in graceful procedures and glitch in centuries of ritualized social food etiquette, the luxurious white space on the table cloth and within the menu? Useless design as the "entremet" that could shake the concept of "meal" entirely without leaving the guests hungry?

Useless design as...

\section{ENDNOTES}

1. A great summary was published as Snowden answered a series of questions posed by the European Parliament (Snowden, 2014).

2. Zé Cláudio and Maria do Espírito have posthumously been awarded a Special Award within the Forest Heroes Awards as part of UN's International Year of Forests in 2011.
3. Naomi Klein's Shock Doctrine (2008) explores this in greater detail.

4. See Carl DiSalvo's Adversarial Design (2012) for a more detailed account of the intersection between design and politics in relation to consensus vs. dissensus.

\section{ACKNOWLEDGEMENTS}

Thanks, Johan Redström and Carl DiSalvo for great discussions and valuable feedback along the way. Also thanks to the two anonymous reviewers providing extensive critique as part of the submission process. I would also like to thank my fellow doctoral students at Umeå Institute of Design for their input and reflection, as well as the institution itself for supporting this journey. A big thanks also goes to the editors of Artifact for their patience and encouragement. Finally, a very special thank you to Leyla Nasib.

\section{REFERENCES}

Adamson, G. (2003). Industrial strength design. How Brooks Stevens shaped your world. Cambridge, MA: MIT Press.

Appelbaum, J. (2014, January 30). Art as evidence. Hashes to ashes. Lecture conducted at Transmediale 2014, Berlin.

Bardzell, J., \& Bardzell, S. (2013). What is "critical” about critical design? CHI'13 Proceedings. NY: ACM.

Beetz, C., Pedersen, J. U., \& Tornbjerg, 0. (Producers), \& Poulsen, F. P. (Director). (2010). Blood in the mobile [film]. Copenhagen \& Berlin: Koncern TV- og Filmproduktion, Chili Film \& Gebrueder Beetz Filmproduktion.

Blyth, M. (2013). The austerity delusion. Why a bad idea won over the west. Foreign Affairs, May/June 2013. Retrieved December 9, 2014 from: http://www.foreignaffairs.com/ articles/139105/mark-blyth/the-austerity-delusion.

Burgierman, D. R. (2011). The tree, the couple who knew the tree and the new design. In Duarte, F. and Bruinsma, M. (Eds.) Useless, The EXD'11 (Experimenta Design) Reader, pp. 89-104. Lisbon: Centauro.

Carelman, J. (1984). Objets introuvables [a catalogue of unfindable objects]. London: Frederick Muller Ltd.

Cisco Visualizations (2014). The city of the future [interactive visualization]. Retrieved December 9, 2014 from http://share. cisco.com/TheCityOfTheFuture/the-city-of-the-future.html

Cross, N. (2007). Designerly ways of knowing. Basel etc.: Birkhäuser.

Cross, N. (1981). The coming of post-industrial design. Design Studies, Vol.2(1). http://dx.doi. org/10.1016/0142-694X(81)90023-5.

DiSalvo, C. (2012). Adversarial design. MA: MIT Press.

Ducks Are the Best. (n.d.). Retrieved from http://ducksarethebest.com/

Dunne, A., \& Raby, F. (2009). A/B, a manifesto. Retrieved from http://www.dunneandraby.co.uk/content/projects/476/0 
Dunne, A., \& Raby, F. (2014). Speculative everything: design, fiction, and social dreaming. Cambridge, MA: MIT Press.

Flaubert, G. (2013). [1856]. Madame Bovary. Madison, WI: Crickethouse Books.

Gaver, W. Beaver, J., \& Benford, S. (2003). Ambiguity as a resource for design. CHI'03 Proceedings of the SIGCHI Conference on Human Factors in Computing Systems. NY: ACM.

Gonzatto, R.F, Van Amstel, F.M.C., Merkle, L.E, \& Hartmann, T. (2013.) The ideology of the future in design fictions. Digital Creativity, 24:1, 36-45. http://dx.doi.org/10.1080/14626268.2 013.772524.

Has the Large Hadron Collider Destroyed the World Yet? (n.d.). Retrieved December 9, 2014 from http://hasthelargehadroncolliderdestroyedtheworldyet.com/

Hornyak, T. (2002). The chindogu champion. Can absurd analog gadgets help dispel the digital doldrums? Japan Inc. April 2002. Retrieved December 9, 2014 from http://www.japaninc.com/article.php?articlelD=762

Hunt, J. (2003). Just re-do-it: tactical formlessness and everyday consumption in Blauvelt, A. (ed). Strangely familiar-design and everyday life. Minneapolis: Walker Art Centre.

Hunt, J. (2005). A manifesto for postindustrial design. I.D. Magazine, November/December Issue. London: Levelprint Ltd.

Impossible Objects (n.d.). Retrieved December 9, 2014 from http://impossibleobjects.com/

Is My Computer On? (n.d.). Retrieved December 9, 2014 from http://www.ismycomputeron.com/

Jones, J. C. (1984). Continuous design and redesign. In J. C. Jones (Ed.), Essays in design. NY: John Wiley and Sons. (Originally published in Design Studies, 3(1)).

Kawakeni, K., \& Papia, D. (1995). 101 unuseless japanese inventions. NY: HarperCollins.

Kawakeni, K., \& Papia, D. (1997). 99 more unuseless japanese inventions. NY: HarperCollins.

Kera, D. (2014, February 1). Conflict-free minerals and open source hardware: homunculus or minerals baby. The media of the earth: geologies of flesh and the earth. Lecture conducted at Transmediale 2014, Berlin.

Klein, N. (2008). The shock doctrine: the rise of disaster capitalism. London: Penguin.

Leek Spin. (n.d.). Retrieved from http://www.leekspin.com/

Lialina, 0. (2013, October 6). The right to UNDO. We, computer users, demand the right to ... Retrieved December 9, 2014 from: http://userrights.contemporary-home-computing.org/

McDonough, W., \& Baumgart, M. (2002). Cradle to cradle: remaking the way we make things. NY: North Point Press.

Microsoft Office Labs (2009). Microsoft Office Labs vision 2019 [film]. Retrieved July 10, 2015 from: https://www.youtube. com/watch? $\mathrm{v}=8 \mathrm{Ff7SzP} 4 \mathrm{gfg}$

Nelson, H., \& Stolterman, E. (2012). The design way. Intentional change in an unpredictable world. 2nd Edition. Cambridge: The MIT Press.

Norman, D. (2002). The design of everyday things. NY: Basic Books.
Oxfam (2014, January 20). Working for the few. Political capture and economic inequality. Retrieved December 9, 2014 from: http://oxf.am/KHp.

Paglen, T. (2013). “Friends of space, how are you all? Have you eaten yet?" Or, why talk to aliens even if we can't. Afterall Issue 32 (Spring 2013). Retrieved from http://www. afterall. org/journal/issue.32/friends-of-space-how-are-you-allhave-you-eaten-yet-or-why-talk-to-aliens-even-if-wecan-t.

Papia, D. (n.d.). Hey, buccaroos! Yes, this is the ONE AND ONLY official website of the International Chindogu Society. Official Website of The International Chindogu Society. Retrieved December 9, 2014 from: http://www.chindogu.com/.

Please Like. (n.d.). Retrieved December 9, 2014 from http:// www.pleaselike.com/.

Pointer Pointer. (n.d.). Retrieved December 9, 2014 from http:// www.pointerpointer.com/.

Prado de 0. Martins, L. (2014). Privilege and oppression: towards a feminist speculative design. DRS2014 Conference Proceedings. Umeå: DRS2014. Retrieved December 9, 2014 from http://www.drs2014.org/media/654480/0350-file1.pdf.

Rampell, C. (2013, October 29). Cracking the Apple trap. It's the economy. NY Times. Retrieved December 9, 2014 from http:// www.nytimes.com/2013/11/03/magazine/why-apple-wantsto-bust-your-iphone.html? $r=1 \&$.

Redström, Johan. (2008). RE:Definitions of use. Design Studies, 29(4), 410-423. http://dx.doi.org/i.destud.2008.05.001.

Redström, J. (2011). The useless within. In Duarte, F. and Bruinsma, M. (Eds.) Useless, the EXD'11 (Experimenta Design) reader, pp. 89-104. Lisbon: Centauro.

Rosenbak, S., \& Streinzer, A. (forthcoming). Re-valuation: an urgent design call for reappropriating "currency." CumulusDublin Conference Proceedings. Dublin: NCAD.

Snowden, E. (2014). [Testimony to European Parliament]. The European Parliament. Retrieved December 9, 2014 from: http://www.europarl.europa.eu/document/activities/cont/201403/20140307ATT80674/20140307ATT80674EN.pdf.

Thackara (2013, December 19). Republic of salivation (Michael Burton and Michiko Nitta) [weblog post/discussion thread]. Design and Violence. MoMA. Retrieved December 9, 2014 from: http://designandviolence.moma.org/ republic-of-salivation-michael-burton-and-michiko-nitta/.

The Ten Chindogu Tenets (n.d.). Official website of The International Chindogu Society. Retrieved December 9, 2014 from: http://www.chindogu.com/index.html.

Thorpe, A. (2012). Architecture \& design versus consumerism. How design activism confronts growth. London: Earthscan/ Routledge.

Tonkinwise, C. (2005). Is design finished? Dematerialisation and changing things in A. M. Willis (Ed.), Design philosophy papers, collection two. Ravensbourne, Australia: Team D/E/S Publications.

The Useless Web. (n.d.). Retrieved December 9, 2014 from http://www.theuselessweb.com. 


\section{CORRESPONDENCE}

Søren Rosenbak

Umeå Institute of Design

Umeå University

90187 Umeå, Sweden

Mobile: +46761449258

Email: soren.rosenbak@umu.se

Published online 28 July, 2015

ISSN 1749-3463 print/ISSN 1749-3471

http://dx.doi.org/10.14434/artifact.v3i4.9468

(C) 2015 Artifact

Copyright to illustrations in this article resides with the creator unless otherwise noted. Artifact publishes illustrations in accordance with commonly acknowledged fair use of visual materials for non-commercial research purposes. Creators who feel that publication is in violation of copyright or fair use should contact the editors. 